\title{
Back to where it all began ...? Reflections on injecting the (spiritual) ethos of the Early Town Planning Movement into Planning, Planners and Plans in post-1994 South Africa
}

\begin{abstract}
Author:
Mark Oranje ${ }^{1}$

Affiliation:

${ }^{1}$ Department of Urban and Regional Planning Faculty of Engineering, Built Environment \& IT, University of Pretoria, South Africa

\section{Note:}

This article forms part of the special collection on 'Doing urban public theology in South Africa: Visions, approaches, themes and practices towards a new agenda' in HTS Teologiese Studies/Theological Studies Volume 70, Issue 3, 2014. The collection is the result of the project 'Urban Public Theology', which was initiated by the Institute for Urban Ministry but later expanded to include several academic departments and institutes at the University of Pretoria (UP) and University of South Africa (UNISA). The leading centres in this regard were the Centre for Contextual Ministry (UP) and the Research Institute for Theology and Religion (UNISA).
\end{abstract}

Correspondence to: Mark Oranje

Email:

mark.oranje@up.ac.za

Postal address:

Department of Urban and Regional Planning, University of Pretoria, Pretoria 0002, South Africa

Dates:

Received: 08 July 2014 Accepted: 06 Aug. 2014 Published: 20 Nov. 2014

\section{Read online:}

Recent developments in South Africa in the field of planning, the domain of plans, and the world of planners, would suggest that planning and plans are viewed in a positive light, the local planning profession is in good shape, and these instruments and actors can play a meaningful role in the development and transformation of the country. In this article, these assumptions were explored through the lens of the attributes and convictions that gave birth to and drove the early 'town planning movement' in the industrial cities of North America and Western Europe. A key theme in this analysis was the role played in the early town planning movement by compassion, passion and care for progressive change, and the conviction that it was possible to do so through the application of reason, technical ability and ingenuity. Based on this analysis, the argument was put forward that, while planning, plans and planners in South Africa could potentially play a crucial part in the crafting of a different country, a number of crucial changes would need to be made. The challenges associated with effecting these changes were subsequently explored, and the article concluded with a proposal for doing so by tapping into the metaphors as deployed, and the drive and passion as displayed by those in the early town planning movement.

\section{Introduction}

Over the last few years, a series of highly publicised long-term development plans were adopted, the long-awaited national Spatial Planning and Land Use Management Act was passed, and job advertisements for planners and calls for proposals for planning-related work have increasingly tended to include registration with the South African Council for Planners as a requirement (see City of Tshwane 2013; Gauteng Provincial Government 2014; National Planning Commission 2012; Republic of South Africa 2013). As such, it could easily be assumed that planning and plans are held in high regard, the planning profession is in good shape, and planning and plans are viewed as vehicles for 'bringing about a better future' for the country.

In this article, this view on planning, plans and planners is questioned. Starting with the birth of modern town planning in the industrial cities of Western Europe and North America, and from there making its way through the dawn of town planning in early twentieth century colonial South Africa to current day post-apartheid South Africa, the argument is made that there are certain crucial ingredients for a societal and political buy-in to, and institutional anchoring of, planning. These ingredients, it is argued, are not present in South Africa today. It is furthermore held that planning, plans and planners can play a key role in the creation of a very different society, but that this will require a number of considerable changes to be made.

After a section in which the appetite for the kind of changes that would be required and the possibility of effecting such changes are pondered, a proposal is made for the injection of the idealism of the early town planning movement when it was less about professional status and recognition and more about true conviction, impassioned preaching, belief and action, into planning, plans and planners. This story requires no previous exposure to planning and given its trajectory from 'social movement to just another job in a bureaucratic institution', may strike a chord with readers from other disciplines or fields of endeavour who have made similar journeys.

How to cite this article: Oranje, M., 2014, 'Back to where it all began ...? Reflections on injecting the (spiritual) ethos of the Early Town Planning Movement into Planning, Planners and Plans in post-1994 South Africa', HTS Teologiese Studies/Theological Studies 70(3), Art. \#2781, 10 pages. http://dx.doi.org/10.4102/hts.v70i3.2781

Copyright: @ 2014. The Authors. Licensee: AOSIS OpenJournals. This work is licensed under the Creative Commons Attribution License. 


\section{It is said that ...}

There once was a time when the pleas for the institution of city planning and the creation of 'a better city' had a connection to a 'higher calling', when the approach, language and metaphors of planning were inspired by religious teaching and belief (Hall 2002; Mackintosh \& Forsberg 2013; Oranje 1998; The Royal Institute of British Architects 1911; Ward 2004). For some, in the heady late nineteenth and early twentieth century-days of rapidly-rising modernism in Europe and North America - that is the 'birthdate' of what was later labelled 'modern town planning' - it was about creating a city suitable for a society as envisaged in the Christian teachings of equality, love, care and compassion; for others it was about cautiously building a stage fitting for the return (the 'Second Coming') of Christ (Butterworth 2010; Hall 2002; Mackintosh \& Forsberg 2013). This call to a higher cause not only acted as a dynamo for the zealous proponents of this new urban pursuit (part religion, part 'contained revolution'); it also provided a powerful way of raising awareness, drawing in followers (familiar with biblical scripture), challenging sceptics and non-believers, and making disciples of 'the (planning) faith' (Mackintosh \& Forsberg 2013; Krieger 1972a). Key to this endeavour was the utilisation of a series of powerful religious metaphors drawn primarily from Christianity, notably those of:

- the 'New Jerusalem', as revealed and defined in the book of Revelation

- the 'fallen city', as epitomised in the biblical cities of Sodom and Gomorra, as centre of 'sin' and now relived in the Industrial City of the day

- human frailty and failure ('sin') and its fallout in the lives and living spaces of those who live in this hellish city

- a prophecy of doomsday/the end, should nothing be done about the fallen city and its inhabitants, again as drawn from the book of Revelation

- deep and real remorse, coupled with a serious wish for and commitment to change, repair, healing and renewal

- salvation, through action - not just any action but purposeful action driven along by faith, by the belief that it is possible to not just repair, but also to build a new and better city, and informed by a thorough understanding of the situation on the ground (Krieger 1987a; Oranje 1998; see Lilley 2004).

While steeped in Christian faith, and with their eyes set on the heavens, the instruments of the 'early town planning movement and planners' were the earthly activities of science and the application of 'the scientific method' (i.e. research), and artistic expression and endeavour (Culpin 1913; Geddes 1915; Hall 2002; Mallows 1965; Nettlefold 1914; Robinson 1911). This relationship with science was a dualistic one, with science on the one hand being respected and valued for having, amongst others, given humanity the steam train, electricity and the printing press, emboldening thinkers, and creating an aura of 'anything is possible', while on the other hand, being disdained for having created the Industrial City of ultimate darkness and its poisonous simmering brew of exploitation, instability and chaos - a 'world out of control' spiralling (rapidly) downwards towards the eternal fire (Geddes 1915; Nettlefold 1914; Oranje 1998; Robinson 1911). The connection with art was equally dualistic, with on the one hand a rapidly-accelerating escape from realistic, 'photographic' representation to abstraction, impression and expression, and which was increasingly attributing art to human ingenuity, gaining pace, while on the other hand, many still seeing artistic talent as a gift from the heavens that had to be revered and used to serve the Creator and capture and celebrate Creation in as true or realistic a way as possible (see Jack 1912; Lilley 2004; The Royal Institute of British Architects 1911). In many ways it was a strange coming together of the belief that it is necessary to do something about a fallen/damaged world and the conviction that it is possible to actually do so successfully through human endeavour (hard work, intellectual agility and creativity) (Krieger 1987a). As such, it could be likened to a 'secular religion' displaying both Catholic elements in its recognition of sin and the need for remorse and repair, and Protestant virtues in its approach to taking responsibility for failure and for 'setting things right'. This spirited, creative and reason-fuelled singularity would over time lead to the creation of a distinct area of work ('urban/town planning') with as its workshop and place of focus the cities of late nineteenth and early twentieth century North America and Western Europe (Cullingworth 2006; Culpin 1913; Hall 2002; Jack 1912; Robinson 1911; Ward 2004). This acceptance and incorporation into the state machinery of this new discipline and area of work was in many cases a hard-fought victory against powerful interests who saw no need for meddling social activists, and who fiercely opposed it for this reason. What eventually swayed leaders in the nascent nation states of the day was the acute concern they shared with the early planners of this turbulent zone of production, trade, finance, power and unrest that was the Industrial City (Aldridge 1915; Cullingworth 2006; Rydin 1993; Ward 2004). A key reason for this being that as meddling as the instrument was, it held out the promise of order, beauty, healthier, stronger and hence more productive workers, and very importantly, stability, none of which were undesirable attributes in the eyes of the industrialists or the propertied classes (Aldridge 1915; Rydin 1993; Ward 2004).

What this early period demonstrates is that, even though the world in which this simple, yet powerful metaphor-laced tale of sin, remorse, redemption and salvation, coupled with its dire warning on the wages of sin was unleashed was often hostile and filled with vested and powerful interests, its proponents were able to have it incorporated as an institution within the broader institution of the nation state (Aldridge 1915; Hall 2002; Krieger 1987a; Ward 2004). It was, however, also this institutionalisation that would lead to its entrapment and closing down of its revolutionary, transformative power. As to how this came about at the time, it may be that this is 'the way of the world' where social movements that start off with fervour, passion and belief are concerned, thus those in power use the instrument for their own objectives and not those of the movement. It may also be as a result 
of the way in which the institutionalisation was done at the time, through rudimentary legislation that was all about instilling order through strict regulation and had no place, 'code' or language for passion, belief and change. Whatever the reason or sets of reasons, the outcome was the end of the early, revolutionary organic town planning movement in a state bureaucracy; very much as some believe the first, early, organic Christian movements became entrapped in church and church-state-meshed bureaucracies (Evans 1994).

Once it was part of the state bureaucracy, the 'town planning movement' moved from what Berman (1989:243) labelled 'modernisation as adventure' to 'modernisation as routine', in which the urge for transformation, rejuvenation and change was subsumed by the task of serving and maintaining the world as created by the modern state. The crude but modest requirements of this latter task would lend itself to the emergence of a 'broad-spectrum profession' in which initially a motley crew of architects, engineers, health officials and surveyors were involved; later giving rise to the creation of a distinct profession, coupled to university programmes by which access to the profession could be gained and in which a clear set of rules and a structured socialisation scheme could ensure a predictable and reliable reproduction model (Rydin 1993; Ward 2004). In this model, the early idealism and dreams of radical change and the heaven-eyed crafting of a fair, just and productive city would increasingly find its way to the vaults of 'planning history' - narrated and presented as a distinct era of utopianism and megalomania, of dreams without reality and dreamers without a destiny (see Hall 2002; Oranje 1998). Filling the void left by the departure of care and concern would be an essentially elitist, often-even patronising mixed-up, cut and paste project of normative positions and thoughts about 'doing good and being right' (Hoch 1984), which would be presented as 'Planning Theory', and increasingly be written by a new special class of planner - the 'planning theorist' (see Allmendinger 2009; Hagen 1998; Hoch 1984, 1992; Krieger 1974; Oranje 1998; Taylor 1998). This new, strongly normatively-angled creation, that is, 'Planning Theory', would in its later cynical, morbid, angry, deeply introspective postmodernist stages also entail a series of startling, sardonic knife-in-own-heart-slowly-turning disclosures about 'the dark side of planning' and the twisted, even evil intents and nefarious power-soaked collaborations of planners (Oranje 2002). In all of this, the historical gleam of the victorious tale in which planning (and planners) came into the world to create a better world was lost, despite its initial significance and crucial importance in selling and believing in, and institutionally harbouring and funding it. The loss of its founding rationale and the remaining, otherwise scanty set of hard technical skills (without the hard, driving edge of social purpose and conviction) would soon lead to planning and planners looking strangely and ironically out of place and time in a neo-liberal world in which return on investment and hard, tangible, sellable skills in support of this greedsoaked pursuit had once again become the sole driver (Sager 2009; Tasan-Kok 2012).

\section{Back home ...}

Despite being thousands of miles away from the Industrial City of North America and Western Europe, the early 20th century 'town planning movement' in the then newly created Union of South Africa initially had some semblances of its first, fledgling manifestations in this very different setting. This was largely due to the acute interest in progressive, 'modern' and fashionable ideas by colonists not wishing to be out of touch, or seen to be falling behind their counterparts in the periphery of the 'civilised world', but also through the transfer of dreams of a better world from soldier to soldier amidst the brutal manifestation of the destructive force of the Machine Age in the trenches of World War One (Bowling 1936; Cornish-Bowden 1925; Howden 1917; Mabin \& Smit 1992; Oranje 1998; Pearse 1938a, 1938b; Thompson 1924; Waugh 1928). At the same time, in the simmering aftermath of the Great South African War (1899-1902), the clash between capital, labour and state that had plagued the then South African Republic on the Witwatersrand Gold Fields in the last two decades of the nineteenth century had become more extreme, now also as there was the presence of a new destitute Afrikaner working class 'driven to town' by the destruction of the agricultural sector in the war, and a series of devastating droughts (Bossenbroek 2012; Davenport 1989; Giliomee 2003; Mabin \& Smit 1992). With the newly established State, consisting of four provinces, still struggling to find its feet, establishing its authority, and determining 'who does what' in terms of powers and functions, and a massive town-ward movement underway from rural South Africa, a space was created for highly profitable land speculation and piece-by-piece urban expansion (Callinicos 1987; Floyd 1960; Hamlin 1934; Mabin 1991a, 1991b; Oranje 1998). As such, highly receptive conditions in the eyes of the powerful for a State-activity like town planning were being created, that is public health, safety and civil unrest threats or concerns in slums; cluttered roads, with no overall planning for the vehicles of the captains of the machine age, notably the car; and potential loss of value in land and investment due to the unregulated transformation of farmland into residential areas (Coaton 1934; Mabin 1991a, 1991b; Oranje 1998; Parnell 1993). Layered over this was the 'mixing of races' in the slums of the rapidly expanding urban areas on the Witwatersrand. This challenged the prevailing idea of separation of races and the eugenic conceptions of the superiority of Europeans, and swept under the colonial carpet questions about the exclusion of black South Africans from the creation of the Union in 1910, and the earlier established racially-based right to own land on the profitable Witwatersrand Gold Fields through legislation dating back to the late nineteenth century Kruger government (Bossenbroek 2012; Christopher 1984; Oranje 1998).

These challenging conditions (for the powerful) would see the focus falling on primarily public health and housing and being given State attention and funding through legislation, and not on 'town planning'. It would be more than two decades after Union formation that the first town planning 
legislation, in the form of provincial ordinances, was passed first in the Transvaal in 1931, and thereafter in the other three provinces over the next two decades (Mabin \& Smit 1992; Oranje 1998). This legislation, largely based on the earliest, still-very-tentative and largely 'experimental' examples of such legislation in England in 1909 and 1919, was, however, a far cry from the progressive ideals of those in the town planning movement. It was more about the regulation of transformation from farmland to urban land than about the preparation of grand modernist schemes for the salvation of those living in modern, 'out-of-control urban monstrosities' (Muller 1983, 1991; Oranje 1998). As such, and through these myopic ordinances, town planning was primarily defined as control and regulation - the zoning of land, the freezing of land-use profiles, and the control of settlement expansion and not about improving urban spaces, lives and life chances through the informed head and able hand of the State (Muller 1983; Oranje 1998). At the same time (i.e. during the 1930s), national legislation, in contrast to the provincial town planning ordinances, was passed on slums, roads and road planning (Oranje 1999, 1998). These legal expressions not only established the pecking order amongst town planning, roads and housing as domains or sectors of interest, but also relegated town planning and its proponents to a subservient role, far behind roads and housing, which the then State saw as crucial for the control and reproduction of established colonial economic and social relationships - a far cry from 'the progressive, purposeful planning of and for urban areas' (Muller 1980, 1983, 1991; Oranje 1999).

These already ominous developments for the fledgling and struggling local town planning idea or movement worsened further when town planning became a distinct profession in the second half of the century. In this process it not only shed the little activism and social movement-feel it had, but also lost a key body of idealists - a group of young modernist architects who had been drawn to town planning largely as a result of the excursions of architects in Europe into it and who held the belief that grand-scale town or urban planning held the potential to create earth-based utopias (Muller 1983; Mabin \& Oranje 2014). In a short span of time, the half-opened eyes of the movement turned from the heavens to lines in the sand - notably the lines of the land surveyors who were the major beneficiaries of the introduction of strong State regulation, surveying and registration or recording of urban land development. It was incidentally primarily also this group that would take the postgraduate diploma courses in town planning, and who would begin to refer to themselves as 'town planners' (Oranje 1998; Prinsen 1966). The fact that the main driver for land surveyors and architects to venture into 'town planning work' was to make an income in times when architecture or land surveying work was in short supply further eroded the image and standing of planning in the eyes of notably the other built environment professionals (Oranje 1998). And so, when the first distinct undergraduate 4 -year town planning courses were introduced in the 1960s, the profession had been firmly established as a sober, comparatively low-paying, technical profession; its key areas of focus were land-use regulation and the drafting of residential neighbourhood plans for new settlements or extensions to existing settlements for paying clients, be they public sector entities or private land developers (Muller 1980, 1983; Oranje 1998).

The bottom-of-the-pack-position of the town planning profession in relation to the architects, engineers and land surveyors, which had been established in the 1930s and 1940s, the drab nature of the work, and the connection of the profession to 'doing-it-on-an-economic-need-to-do basis' would frame and entrench the relationship between the profession and the increasingly draconic apartheid state. Key to this relationship was that, in its wish to be accepted, the small group in the new town planning profession dared not question authority (and very likely had no wish to do so either) and would do as it was told (Muller 1991, 1983; Oranje 1998). This submissive selling out to the powers that be or were, saw the 'space inhabited, thought about and worked in by planners' shrink ever further and further. It led to the development of a practice-is-all mentality in the profession, in which that which was learnt and done in the workplace was the norm and academia regarded as little more than an initiation school (hurdle) that prospective 'operators' needed to go through to obtain access to 'the real learning school' - the increasingly myopic world of practice (Muller 1983; Oranje 1998). As such, this view ran directly against two threads of the utopian roots of its founders - siding with the powers that be, and instead of questioning, contesting and attacking the status quo, assisting in cementing it, and assisting in creating racially separated and economically stratified urban spaces, and maintaining and deepening their resulting unequal social and economic relations (Muller 1991, 1983). In its local, South African guise, 'town planning' would go from 'hearing of and slightly dreaming of the New Jerusalem in a senseless trench war on fear-and-blood-drenched battlefields in western Europe' to assisting in the artificial creation and retention of the New Jerusalem for a few. It assisted in entrapping the majority in trenches on its outskirts, close enough to be shepherded to it on a regular base to serve its privileged inhabitants and sweep and polish its streets of gold, but far away enough to not spoil the view, and to kill off any suggestion that living in it was even a remote possibility for those living in the trenches (Mabin 1991a, 1991b; Parnell \& Mabin 1995). Save for a few isolated spurts of hope, belief and dreams of 'a better world through planning', the town planning profession became a handmaiden of the state, utter-eager to please and to be accepted as a profession. In the process it was becoming closely associated with the few, the wealthy and the powers that be, while at the same time becoming deeply tarnished with the hate-and-fear-drenched darkness that apartheid, and especially the Apartheid City, was for the 'en-trenched' and excluded 'many' (Mabin \& Smit 1992; Muller 1983; Slabbert 1994; Smit 1989; Parnell \& Mabin 1995).

By the time the profession arrived with, and not ahead of, the rest of old South Africa in the 1990s, it was in a very strange 
place (Oranje \& Berrisford 2012). For one, it had only a few years earlier seen the passing of legislation (in 1985) that created a statutory registration and oversight professional body, laid down rules for registration, and provided for accreditation of planning programmes at tertiary institutions. On another level, its uncritical provision of technical services to the apartheid state 'on the ground', and in some cases, in the planning of its macro-spatial manifestation (through the preparation of grand-scale national plans for the Bantustans) and more regional and local level unfurling (through the identification and establishment of homeland towns and heavily subsidised outlying 'industrial estates' stripped of any economic logic) left it in a precarious position - not just as to 'what it had done', but also, whether it was able to assist in undoing the damage, given what its competencies were and where, how and to what intent these capacities were developed (Oranje 1998). Adding a further layer to this complex situation was the presence of a body of progressive planners, many of them (the younger ones) trained in planning programmes where apartheid and the apartheid state were strongly critiqued, and a few older ones, who had over the years made clear their disdain of and opposition to the prevailing unequal and unfair system (see Mabin 1991a; Muller 1991; Oranje \& Berrisford 2012; Smit 1989). The tainted, morally bankrupt, internally fractured state of the profession meant that, while some of the more progressive planners in the profession could, and were, readily absorbed by the new post-apartheid administration and were involved in development of new legislation, policy and procedures post-1994, the profession as an entity was not leading or giving strategic guidance (Oranje \& Berrisford 2012; Van Wyk \& Oranje 2013). In contrast to days gone by, it was not so much fighting for attention and recognition, but caught up in resolving its inner struggles and tensions, while at the same time desperately trying to ensure its survival. The absence of leadership in and stature of the profession, would, amongst others, contribute to the slow pace of adopting new planning legislation and putting in place a new planning system in the country, and see 'a silence on space' and subsequent absence of a spatial dimension in many development plans, frameworks and strategies prepared in the first 10-15 years after democracy (National Planning Commission 2012; Oranje 2012; Oranje \& Berrisford 2012; Van Wyk \& Oranje 2013).

Having (somewhat) surprisingly survived the transition from apartheid, the profession has over the course of the last 5-10 years been clawing out a place for it in post-1994 South Africa in the domains of development and planning. At the same time, and most probably not unrelated to the profession's problem of low self-esteem and its near death experience in the 1990s, it has embarked on a drive for work reservation, alongside a general trend in government towards professionalisation of the public sector (see Department of Rural Development and Land Reform 2013). The broader resurgence in planning can most likely be attributed to a combination of factors, notably:
- the growth in the membership of the planning body of post-1994 trained planners for whom professional status (and its accompanying status and income portfolio) is a crucial area of concern, and who do not have the baggage of the past

- the arrival of new leadership in the institutions of the organised profession

- the ease of international connectivity and the dissemination, deliberation and popularisation of ideas

- the picking up, re-establishing and strengthening of intellectual connections between planners involved in higher education, research councils, non-governmental organisations (NGOs) and more policy-focused planners with their international counterparts, notably also on the African continent

- a realisation and recognition that 'space matters', and that it will need to be considered, factored into and acted in and upon in all plans to address the legacies of apartheid

- the growth of the ecological movement and the evermore persuasive arguments and physical manifestations of global warming and climate change

- the passing of new spatial planning and land-use management/regulation legislation, 13 years after the first Bill to this effect was published (National Planning Commission 2012; Oranje \& Berrisford 2012; Republic of South Africa 2013).

At the same time, and intertwined with some of the drivers behind the resurgence of the town planning profession and the growth of the stature of the profession itself, there has been a move towards the longer-term future in a number of areas of work, disciplines and government. This has amongst others manifested in a 2011/2012 Cabinet-endorsed longterm development plan for the country (the 2030 National development plan) and a sleuth of downstream 2030 plans either being prepared or considered by provincial and municipal governments. These include a long-term infrastructure plan and transport plans for the country as a whole, a 2055 plan for Gauteng (its end date 100 years after the adoption of the Freedom Charter at Kliptown by the African National Congress (ANC) and its partner organisations), and a 2055 plan for the City of Tshwane (City of Tshwane 2013; Gauteng Provincial Government 2014; National Planning Commission 2012; Republic of South Africa 2013).

With all of these positive developments, apartheid slain, a planning profession growing in stature, enabling legislation and policies and a government in support of long-term planning, it would seem that the scene is set for planning, plans and planners to bring about major changes in the country and to dramatically alter the country for the better (Oranje 2012). It would not even be too far-fetched to believe that planning, plans and planners in South Africa today were 'in a similar place' and had similar intentions and potentialities as those in the industrial cities in Western Europe and North America, and that a very different future was in the making and even on its way. Yet, as the 'New Jerusalem' is best experienced under foot and on the skin, it deserves asking: is this hopeful view valid, is the New 
Jerusalem in the making, and will there be enough place for 'all' in this new city, and enable all of us to have a decent quality of life, given its original design for only a small segment of South Africans?

\section{A view on planners, planning and plans in current day South Africa}

A key driver in the birth and rise to prominence of the early town planning movement was the belief of its protagonists in the power of science, reason, creativity and ability, coupled with a belief in the positive outcome of such actions. Driven by their religious belief, they articulated these in terms of the metaphors of this creed, which was not only a simple, powerful recognisable text but also a language and set of constructs that those whom these planners were speaking to (i.e. the powers that be and 'the masses' whose lives it sought to improve) were very familiar with and understood. In contrast to the situation in pre-1994 South Africa, the early protagonists were in many cases not pushing for the introduction of planning for their own benefit, as many of them were successful in their own right, and did not need 'planning work' to make a life (Hall 2002; Mackintosh \& Forsberg 2013; Oranje 1998).

Read against the backdrop of the birth of planning in the industrial cities of Western Europe and North America, the traits of belief, passion and total commitment are not that recognisable in the planning fraternity in South Africa today. While planners may talk about change when engaging communities and stakeholders and in the advice they provide to decision-makers on applications for land development and land-use change, the plans they prepare and review show little of the passion of the early planners. Without such visible manifestations of passion, belief and conviction, communities are left in the dark as to whether 'it actually is there'. Whereas those in the service of churches and religious organisations have the advantage of clearly being in the employ of something greater, which incidentally is also familiar to those in their congregations, and as such do not necessarily have to show, gain or win and retain their belief and trust, planners need to do all three of these, not once, but all of the time. And, in contrast to the passion for communities, it would seem that what excites planners is not 'what is wrong in the world', and 'what needs to be done about it', but rather their careers, salary packages, promotion, moving on in the organisations they work in, and their professional interests (Oranje \& Radebe 2012). In most administrations, planners are not distinguishable by any specific trait from any other public official.

With the focus on professionalisation in government, and the increasing emphasis on professional registration, the profession and having a degree that allows for such registration have become major concerns. This, in turn, has fuelled a surge in numbers of applications for admission to postgraduate planning programmes that enable such registration, and registration as a professional planner. Another area of keen interest has been work reservation, which the professional council is actively pursuing, and which has had a similar result as the pursuit of professionalisation. While planners admittedly do not live on an island, and may be inhibited and frustrated by politicians who do not allow them to play the roles that they possibly could, it is hard to believe that this is the key reason for the lack of passion and enthusiasm in the profession, or that this is an issue that 'a passionate planner' is unable to overcome.

The plans that are being prepared are equally uninspiring. About the municipal Integrated Development Plans (IDPs) and Spatial Development Frameworks (SDFs) much has been written, with many authors and reviewers of such plans commenting negatively on their increasingly stale, user-unfriendly presentation style; voluminous form; standardised, guideline-driven nature; and mechanistic, outdated, meaningless form of 'community participation' (Coetzee2012; Harrison 2006; Merrifield, Oranje \& Fourie 2008; Adam \& Oranje 2002; Oranje \& Van Huyssteen 2011). These negative attributes not only waste the energy and patience of stakeholders and communities, but also show a lack of recognition for the unique role and sustained contribution that is required from 'all' in the preparation, implementation and review of these plans, as well as their transformative power (Coetzee 2012; Oranje \& Van Huyssteen 2011). The more recent surge of long-term plans and frameworks, such as the 2030 National Development Plan, the 2055 plan for Gauteng, and the 2055 plan for the City of Tshwane suffer from many of the following characteristics:

- Dreadfully long, wordy, filled with data, maps and diagrams, ideas, perspectives and paradigms that overwhelm the reader and do not offer a simple, strong narrative, list of characters (role players and roles and responsibilities), or set of easily understandable metaphors, and lacking in a compelling, coherent, clear argument to ensure buy-in from a diverse body of readers.

- Limited specification as to how the territory the plan refers to (be it South Africa as a whole, a particular province, or municipality) will be transformed from a space planned and developed for a minority to one catering for six to ten times as many people.

- Not so much a disconnect with plans, budgets and programmes prepared in other sectors and spheres of government as a lack of specification as to what the relationship between the various instruments is, and what the status of these long-term development plans is in relation to the other plans and instruments (i.e. are the long-term plans 'Alpha plans', and if so, how do the other plans tie in to and support/assist these plans, how is this integration/alignment to be achieved, and what is the 'penalty' for failing to do so?)

- Far too little detail as to what would happen in the world, to the places and to the people that the plan speaks about, should the plan not be implemented, thus far too few and far too few powerful and compelling images of the cost of failure, or inertia, to force the issue and to secure buy-in and implementation of the plan. 
- Lofty long-term vision statements that provide very little detail as to what can be expected, and what should happen in the in-between years in terms of who must do what, by when, for how long, and for what reason, which makes these plans massive open-ended statements of all that is good and proper and that readers/users can pick from to suit their individual programmes and projects as, when and where it suits them - in a way providing a cupboard filled with rows of hangers on which to hang projects and programmes as, where and when it suits those who have to 'align their actions with these longterm plans'.

- Far too glossy a finish and presentation, creating the impression more of a coffee table book than of a serious, gutsy, strategic plan for urgently-required change and transformation (see Krieger 1975, 1987b; Oranje 2012).

What has happened in many a government department and municipality since the adoption of these long-term plans, notably so the National Development Plan, is that instructions have been given to officials to 'align' all their activities with the plan without little, if any, consideration being given to crosscorrelation, synchronisation and alignment amongst all these (now) 'long-term plan-aligned projects and programmes' in the various entities (departments, units, municipalities). This ad hoc-future focus is worsened by these plans not coming across as definitive long-term statements of intent that will outlive the administrations that prepared them, which is one of the explicit reasons often put forward for preparing such long-term plans (Oranje \& Merrifield 2010).

Whether it is planners or the nature of the systems in which they find themselves, planning, as a 'discernible thing that planners do', is known more for its multitude of meetings, legal compliance, adherence to strict guidelines, endless ticking of boxes, preparation of progress reports and lack of implementation than for its scientific rigour, explorative, creative, activist spirit, or passionate pursuit of outcomes and compelling narration of desirable futures, coupled with a clear exposition of the serious prospect of doom (Krieger 1975, 1987b). As such, neither the profession, nor that which its members do, or its products (plans, policies, strategies, frameworks, etc.) and outcomes, are discernible or reminiscent of the ideals and passions of the protagonists of the early town planning movement. This does raise the question as to whether post-apartheid planners are really that different to those of apartheid South Africa who had fulfilled the role of handmaidens of the State, were eager to please, gain acceptance and attain professional status and secure a middle class life, instead of standing up for the principles of their creed, and from which those in the Early Town Planning Movement drew their courage. While there surely are exceptions, it is very much a case of no conviction, no passion, no courage ...

\section{A call for spirited change?}

The situation as sketched in this article is one of a profession being more concerned with its own job security and future and less with what it actually offers society in terms of its progressive, transformative roots. This may be said of the profession in other countries as well, or may not even be of concern in 'developed', highly institutionalised societies where planning 'simply is just another job', and one not one viewed as 'very sexy' at that, and hence not attractive enough to draw in 'the right students' (see Oranje et al. 2012). In addition to this, this situation is certainly not new or unique to planning, and may be a far more common concern with social movements, ideologies and belief sets that started off with high levels of passion, belief and commitment on the side of their protagonists, prophets and leaders, only to become absorbed in bureaucratic structures and processes of states. As such, it raises the question whether it is a generic fault in our make-up, in our selves when we start utopian projects like these that seek to take us out of our material selves and into ('higher') places where ideals, hope and belief prevail. Is this maybe a fate that befalls all passionate social movements and crusades - they become institutionalised and caught up in bureaucracies, they become professions, they become mundane, soul-numbing day-to-day tasks, they become one of many aspiring voices, and then, start numbly humming along with a more powerful tune, a tune that provides security and stability and shields them from the dangers, the pitfalls and pains of (daily) life?

And yet, while all of this may be true, it does not make it better, nor does it offer adequate recognition of the unique reality of South Africa, of a country in which a fragile social movement was barely given time to breathe before it was institutionalised during a dark era in which a modern nation state was being built around a minority in society, and in which all the institutions of that state were fashioned around the interests of a minority group, notably the most powerful members of that group. In the case of planning, that which became organised, thus bureaucratised planning, was a pale, stripped down, passionless, technical creature focused on land-use regulation and the drafting of layouts. With the country now having to be developed for six to ten times as many South Africans, and with visionary, transformative planning, plans and planners required for the task, the mundane, disinterested style of planning of erstwhile South Africa and the passionless, highly bureaucratised profession is not what is required (National Planning Commission 2012; Oranje 2012). This 'new country' needs a far more caring, compassionate profession and far more of a cooperative style of planning and specification of roles and responsibilities in the processes of plan preparation, implementation and review. It needs planners who are both ready and eager to cooperate, as well as drive and lead such processes, as and where required and/or desired, but also willing and able to allow others to play these roles should they be better suited for the task.

The long-term plans lack strong metaphors, do not make strong, compelling cases for change, do not provide strong enough warnings on failure to act, do not offer ways of embarking on a way forward and towards hope, and have little power to change or direct behaviour (see Krieger 
1987b). Lack of concern with plan implementation and a disregard for specifications around short-term targets and longer-term goals and objectives in such plans do not only challenge the authority of the State, but question the validity of the plan and planning in general, as life continues without adherence to the plan, and makes a mockery of planning, planners and plans. Furthermore, even though communities and stakeholders are invited to become involved and are often engaged in the preparation and review of plans, the participation processes have more of a compliance-form than a conscious-co-preparation, co-ownership and coresponsibility nature (Oranje \& Berrisford 2012). While it is true that community participation is legally sanctioned, these participation processes invariably do not emphasise the crucial importance of co-production in the preparation and review of these plans, and as such do not provide a clear indication as to what the various role players - communities, groups within communities, such as youth, hawkers, owners of businesses, faith-based groups - must bring to the process of plan preparation, implementation, monitoring and review. This model pervades the idea of the State as driver and sole provider, and 'the others' as participants, which is not only a risky venture in a new democracy, but also leads to communities and stakeholders not getting a sense of their own importance or that of others in the preparation of these plans. In addition to this, it leads to communities not getting to know what planners bring to these processes and as such, actually do and contribute to society, why they have something unique to add, why it is worth engaging them, and what they can expect of them.

\section{And so ... what to do?}

Would it make sense to make a call on us as planners to be more passionate about what our profession stood for, to stop being only worried about the here and now, ourselves, our jobs and our immediate family members and relatives, and to care also about the world, the universe, all of us, including 'those who hate us'? Would a reminder of the 'tale' of the care, compassion and passion of the first planners help? Would it be more effective if the message were served in a gentle, caring, compassionate way, or would a hard-hitting, slumber-wrecking ball-type attack be the more appropriate approach or instrument? Would a once-off story, 'the passion of the early planner', be adequate? Would it be of any help or make a difference to make a call for the use of the kind of metaphors that infused the early planners and framed their engagement with the world? Is this a meaningful endeavour, or it is just a futile, naive, elitist view on the complex world of planning and planners from the safety of an academic fortress? Does any of this make sense in a country in which unemployment is stubbornly high, and for whom many of its inhabitants a planning job or position offers a way out of poverty and a first-time entrance into the middle class and everything that goes with this? Equally so, does the lack of engagement on these issues beyond endless empty sets of words from the side of the organised profession, given the desperate situation of the majority of the population, make any sense? Likewise, does the lack of engagement with the planning profession and planners on this matter from the side of communities and community leaders mean they do not believe it would make any difference to the situation should they try, is it a manifestation of a broader lack of trust or faith in institutions in general to change their lives, or is it a case of planning and planners being seen as that insignificant that it (such engagement) does not take place? Is there something to be done, should it be done, and if so, by whom? Or ... is it just the way of the world, or paraphrasing from The mission (Bolt 1986), the way we have planned for and (purposefully) made the world?

While it may be alluring to pretend, forget and just slumber on, giving up on the dream of a better planning profession would be the same as giving up on the dream of a better city a hundred years ago. It would suggest that a profession which has talked about changing the world since its first breath is not interested in, unwilling, or unable to change itself. And so, if one has the passion to see the planning profession change, it surely would be strange if (such a) one could not come up with some ideas as to what it would take to 'set things right' and craft a community of town planning practice based on the beliefs and idealism of the early town planning movement. And hence, in the spirit of choosing not to give up, what follows are some thoughts as to what could possibly be done by one or those in the profession who share(s) the view that there is a need for change, using the metaphors that were used 'way back' at the dawn of the modern town planning movement:

- 'The Fall' - define and describe where the profession went wrong, what the passionate, inspiring movement has become, and what the dire negative consequences of this have been and will be, both for the profession and for those people and places it is meant to serve.

- 'Repent' - recognise 'the wrongs' and agree on the need for change.

- 'Cure' -determine what needs to be done, how it will be done, who will do it and when it will be done.

- 'Heal' - using the cure, fix what is wrong.

- 'Defend' - devise ways to retain the gains of, amongst others, the re-gaining of the soul of the early town planning movement (see Krieger 1974, 1975, 1987).

Who knows, this change may possibly not be pursued, driven and ensured by those in the profession, but by actors and voices that are not in the profession but who share the passion, care and compassion of the early town planning movement. These voices may even start a new movement and provide a home for those who have become deeply disgruntled with their current one, just like religions and (other) social movements often do.

\section{Conclusion}

In this article, the current bureaucratised state of planning, the inability of planning to inspire those it touches and is supposed to serve, and the lack of passion in the planning profession were lamented. The possibility and prospect for reforming the profession was deliberated, and a series of 
actions that may assist in doing so provided. What needs to be done now is to walk the walk, for the time for change is running away rapidly, from all of us.

\section{Acknowledgements}

The author would like to express his sincere appreciation to the editor and the peer reviewers for their kind, valuable and insightful comments, as well as to Dr Stephan de Beer, for his persistence in getting this article written. I do take responsibility for all errors.

\section{Competing interests}

The author declares that he has no financial or personal relationship(s) that may have inappropriately influenced him in writing this article.

\section{References}

Adam, A. \& Oranje, M., 2002, 'A report on engagements with district and metropolitan municipalities on the first round of integrated development plans produced in terms of the Municipal Systems Act, 2000', prepared for the Municipa Demarcation Board and the Department of Provincial and Local Government.

Aldridge, H.A., 1915, The case for town planning: A practical manual for the use of councillors, officers and others engaged in the preparation of town planning schemes, The National Housing and Town Planning Council, London.

Allmendinger, P., 2009, Planning theory, 2nd edn., Palgrave MacMillan, London.

Berman, M., 1989, All that is solid melts into air: The experience of modernity, Verso, London.

Bolt, R., 1986, The mission script - Dialogue transcript, viewed 12 January 2014 from http://www.script-o-rama.com/movie_scripts/m/mission-script-transcriptjeremy-irons.html

Bossenbroek, M., 2012, De Boerenoorlog, Athenaeum-Polak \& Van Gennep, Amsterdam.

Bowling, P.J., 1936, 'Some aspects of town planning', Minutes of Proceedings of the South African Society of Civil Engineers, 107-119.

Butterworth, A., 2010, The world that never was: A true story of dreamers, schemers, anarchists and secret agents, The Bodley Head, London.

Callinicos, L., 1987, Working Life 1886-1940: Factories, townships, and popular culture on the Rand, Ravan Press, Johannesburg.

Christopher, A.J., 1984, South Africa: The Impact of Past Geographies, Juta and Company Pty Ltd, Cape Town.

City of Tshwane, 2013, Tshwane Vision 2055: Remaking South Africa's Capital City, viewed 27 May 2014, from http://www.tshwane.gov.za

Coaton, N., 1934, 'The slum problem', The SA Architectural Record, October, 71-273.

Coetzee, J., 2012, 'The transformation of municipal development planning in South Africa (post-1994): impressions and impasse', Town and Regional Planning 61, 10-20.

Cornish-Bowden, A.H., 1925, 'Site planning', The SA Survey Journal, April, 312-314.

Cullingworth, B., 2006, Town and country planning in the UK, Routledge, London.

Culpin, E.G., 1913, The Garden city movement up-to-date, The Garden Cities and Town Planning Association, London.

Davenport, T.R.H., 1989, South Africa: A modern history, 2nd impression, Southern Book Publishers, Johannesburg.

Department of Rural Development and Land Reform, 2013, Call for Comments on the Draft Regulations for the Planning Profession Act, Act No 36 of 2002, Government Gazette, no. 37009, 08 November 2013.

Evans, B., 1994, 'Theory, sustainability and environmental planning', Town and Country Planning, June, 186-188.

Floyd, T.B., 1960, Town planning in South Africa, Shuter and Shooter, Pietermaritzburg.

Gauteng Planning Commission, 2012, A discussion document on the long-term plan for the Gauteng city-region, viewed 12 February 2014, from http://www. gauteng2055.gov.za.

Gauteng Provincial Government, 2014, Gauteng 2055: A vision for the Gauteng CityRegion, Johannesburg.

Geddes, P., 1915, Cities in evolution: An introduction to the town planning movement and to the study of civics, Williams \& Norgate, London.

Giliomee, H., 2003, The Afrikaners: Biography of a people, Tafelberg, Cape Town.

Hagen, A., 1998, 'Striving for the rationality in planning theory: Logical constructions of "The Grand Theory", or/and painting pictures of "God"?', Working Paper no. 6 viewed 03 June 2014, from http://brage.bibsys.no/xmlui/bitstream/id/102917/ Arbeidsnotat\%20661998.pdf
Hall, P., 2002, Cities of tomorrow: An intellectual history of urban planning and design in the twentieth century, 7th edn., Wiley-Blackwell, London.

Hamlin, E.J., 1934, 'Comments made during a discussion of T.B. Floyd's paper entitled Zoning in its relation to the use of land and buildings', Minutes of Proceedings of the South African Society of Civil Engineers, 69-70.

Harrison, P., 2006, 'Integrated development plans and third way politics', in U. Pillay, R. Tomlinson \& J. du Toit (eds.), Democracy and delivery: Urban policy in South Africa, pp. 186-207, HSRC Press, Pretoria.

Hoch, C.J., 1984, 'Doing good and being right: The pragmatic connection in planning theory', Journal of the American Planning Association 50(3), 335-345. http:// dx.doi.org/10.1080/01944368408976600

Hoch, C.J., 1992, 'The paradox of power in planning practice', Journa of Planning Education and Research 11, 206-215. http://dx.doi. org/10.1177/0739456X9201100305

Howden, R., 1917, 'News and notes', Building 8(II), 117-118.

Jack, J., 1912, Handbook of town planning as applicable to Scotland, William Green \& Sons, Edinburgh

Krieger, M.H., 1974, 'Some new directions for planning theories', Journal of the American Institute of Planners 40(3), 156-163. http://dx.doi. org $/ 10.1080 / 01944367408977465$

Krieger, M.H., 1975, 'What do planners do?', Journal of the American Institute of Planners 41(5), 347-349. http://dx.doi.org/10.1080/01944367508977679

Krieger, M.H., 1987a, 'Planning and design as theological and religious activities', Environment and Planning B 14, 5-13. http://dx.doi.org/10.1068/b140005

Krieger, M.H., 1987b, 'The possibility of doom', Technology in Society 9, 181-190. http://dx.doi.org/10.1016/0160-791X(87)90023-6

Lilley, K.A., 2004, 'Cities of God? Medieval urban forms and their Christian symbolism', Transactions of the Institute of British Geographers 29(3), 296-313. http://dx.doi. org/10.1111/j.0020-2754.2004.00229.x

Mabin, A., 1991a, 'A quarter century of urbanisation: 1965-1990', Town and Regional Planning, 31, September.

Mabin, A., 1991b, 'Origins of segregatory urban planning in South Africa, c.1900-1940', Planning History 13(3), 8-16.

Mabin, A., 1992, 'Comprehensive segregation: The origins of the Group Areas Act and its planning apparatuses', Journal of Southern African Studies 18(2), 405-429. http://dx.doi.org/10.1080/03057079208708320

Mabin, A. \& Oranje, M., 2014, 'The 1938 Johannesburg "Town Planning Exhibition and Congress": Testament, Monument and Indictment', in R. Freestone \& M. Amati (eds.) Planning exhibitions and the development of modern planning culture, pp. 97-110, Ashgate, London.

Mabin, A. \& Smit, D., 1992, 'Reconstructing South Africa's cities 1900-2000: A prospectus (or a cautionary tale)', paper presented at African Studies Seminar, University of the Witwatersrands, Johannesburg, 18 May.

Mackintosh, P.G. \& Forsberg, C.R., 2013, “'Co-Agent of the millennium”: City planning and Christian eschatology in the North American City, 1890-1920', Annals of the Association of American Geographers 103(3), 727-747. http://dx.doi.org/10.108 0/00045608.2011.652888

Mallows, E.W.N., 1965, Teaching a technology, Witwatersrand University Press, Johannesburg.

Merrifield, A. Oranje, M. \& Fourie, C., 2008, 'Dialogue or control? The future of planning in South Africa', prepared for the Presidency and GTZ as part of Government's 15 year (of Democracy) review, unpublished research report.

Muller, J., 1980, 'Planning for people', paper presented at the Planning for People conference, Pretoria, April.

Muller, J., 1983, Theory and practice: The Janus face of planning, inaugural lecture, 02 September 1982, Witwatersrand Press, Johannesburg.

Muller, J., 1991, 'Ethics: Theory and practice in South Africa', Town and Regional Planning 31, September, 17-25.

National Planning Commission, 2012, National development plan 2030: Our futuremake it work, viewed 10 December 2013, from http://www.npconline.co.za

Nettlefold, J.S., 1914, Practical town planning, The St Catherine Press, London.

Oranje, M., 1998, 'The language game of South African urban and regional planning A cognitive mapping from the past into the future', PhD thesis, Town and Regional Planning, University of Pretoria.

Oranje, M., 1999, 'Using South African frames on land use, roads and transport planning and "development" as a counter-frame to the paradigm-based/framed approach to planning and "planning change"', paper presented at the Planning Futures conference, University of Sheffield, Sheffield, 29-31March.

Oranje, M., 2002, 'The postmodern turn', in M. Tewdwr-Jones \& P. Allmendinger (eds.), New directions in panning theory, pp. 172-186, Routledge, London.

Oranje, M., 2012, 'Neoliberalism, shallow dreaming and the unyielding Apartheid City', in T. Tasan-Kok \& G. Baetens (eds.), Contradictions of neoliberal planning: Cities, policies, and politics, pp. 173-204, Springer, Delft. http://dx.doi. org/10.1007/978-90-481-8924-3_10

Oranje, M. \& Berrisford, S., 2012, 'Planning law reform and change in post-apartheid South Africa', in T. Hartmann \& B. Needham (eds.), Planning by law and property rights reconsidered, pp. 55-70, Ashgate, London.

Oranje, M. \& Merrifield, A., 2010, 'National spatial development planning in South Africa 1930-2010: An introductory comparative analysis', Town and Regional Planning 56, 6-6. 
Oranje, M. \& Radebe, W., 2012, 'An ethnographic study of the "new generation of South African planners: Neoliberal, just new, or what?', paper presented at The Annual Meeting of the American Association of Geographers, New York, 24-29 February.

Oranje, M. \& Van Huyssteen, E., 2007, 'A brief history of intergovernmental development planning in post-apartheid South Africa', Town and Regional Planning 51, 1-15

Oranje, M. \& Van Huyssteen, E., 2011, 'Nestling national "transformation" imperatives in local "servicing": space: Critical reflections on an intergovernmental planning and implementation project', Town and Regional Planning 58, 6-16.

Oranje, M., Van Huyssteen, E. \& Venter, S., 2012, Towards a sustainable settlemen collective: Deepening and strengthen professional practice in support of the Urban Networks Programme, prepared for the Neighbourhood Development Programme in the National Treasury, unpublished research report.

Parnell, S., 1993, 'Creating racial privilege: Public health and town planning legislation, 1910-1920', paper presented at the Planning History Study Group symposium South African Planning History, Pietermaritzburg, 06-07 September.

Parnell, S. \& Mabin, A., 1995, 'Rethinking South Africa', Journal of Southern African Studies 21(1), 39-61. http://dx.doi.org/10.1080/03057079508708432

Pearse, G.E., 1938a, 'A survey of town planning in South Africa', The SA Architectural Record July, 231-42.

Pearse, G.E., 1938b, 'Town planning: Proceedings of a congress devoted to town planning', opening address of Architectural Students Society meeting, University of the Witwatersrand, Johannesburg, pp. 9-10.

Prinsen, T., 1966, 'A brief survey of planning legislation in the Transvaal', Diploma in Town and Regional Planning dissertation, Faculty of Engineering, University of Pretoria.
Republic of South Africa, 2013, Spatial Planning and Land-Use Management Act, Act No 16 of 2013, Government Gazette, no. 36730, 05 August 2013.

Robinson, C.M., 1911, The width and arrangement of streets: A study in town planning, The Engineering News Company, New York.

Rydin, Y., 1993, The British planning system: An introduction, MacMillan, London.

Sager, T., 2009, 'Planners' role: Torn between dialogical ideals and neoorg/10.1080/09654310802513948

Slabbert, B., 1994, 'The involvement of planning in Apartheid', paper presented at the Places, people and planning symposium, Pretoria High School for Girls, Pretoria, 26-28 October.

Smit, D.P., 1989, 'The political economy of urban and regional planning in South Africa: 1900 to 1988, towards theory to guide progressive practice', PhD thesis, Department of Town and Regional Planning, University of Natal.

Tasan-Kok, T., 2012, 'Introduction: Contradictions of neoliberal planning', in T. TasanKok \& G. Baetens (eds.), Contradictions of neoliberal planning: Cities, policies, and politics, pp. 1-20, Springer, Delft. http://dx.doi.org/10.1007/978-90-481-89243_1

Taylor, N., 1998, Urban planning theory since 1945, Sage, London.

The Royal Institute of British Architects, 1911, Transactions of a Town Planning Conference, London, 10-15 October 1910.

Thompson, A.J., 1924, 'Practical town-planning in South Africa', The SA Survey Journal, October, 180-192.

Van Wyk, J. \& Oranje, M., 2013, 'The post-1994 South Africa spatial planning system and Bill of Rights: A meaningful and mutually beneficial fit?', Planning Theory, December.

Ward, S., 2004, Planning and urban change, Sage, London.

Waugh, E.H., 1928, 'Town Planning', The SA Architectural Record, December, 226-230. 